\title{
COPPER CHELATING COMPLEX AS IMMUNSTIMULANT OF AFRICAN CATFISH (CLARIAS GARIEPINUS)
}

\author{
HOSSIEN, S.Y. *; ABDEL NABI, M.A.**; NASSAR, A.Y. and IBRAHIM, M.A. \\ *Department of Animal and Poultry Production faculty of agriculture Assiut University \\ ** Department of Biochemistry Faculty of Medicine Assiut University \\ Email: ibrahim.ahmed@mailcity.com
}

\section{ABSTRACT}

Received at: 6/9 /2014

The present study was planned to investigate the effect of dietary supplementation with copper Chelating complex as immunstimulant of catfish Claris gariepinus. Forty acclimated African sharp tooth catfish, were divided into two groups. The first group

Accepted: 19/10/2014 (control group G I) received the basic diet, for 30 days. The second group received the basal diet mixed with $60 \mathrm{mg}$ copper albumin chelating complex/kg basal diet; (G II). At the end of 30 days feeding, the fish of each group were, weight, blood film and serum sample were collected and tested. Fish of each group were challenged by local strain of Aeromonas hydrophila, for challenge. The clinical signs, P.M. lesions and mortalities were also monitored for 7 days post challenge. The obtained results were indicated that copper chelating complex improve the growth rate, and enhance the protective effect against challenge with $A$. hydrophila and potentiate the non-specific immune response through increase the percent of basophile, the lymphocytes and increase the total protein and the globulin in the blood of the treated fish. In conclusion use of copper chelating complex as feed additive for Clariasgariepinus at a dose of $60 \mathrm{mg} / \mathrm{kg}$ diet has shown to be an activator of non-specificimmune response.

Keywords: Immunstimulant, Copper chelating complex, African catfish, Clarias gariepinus.

\section{INTRODUCTION}

During the last decade there was an increasing interest in the modulation of the nonspecific immune response of fish to elevate the general defense barriers and hence increase resistance against diseases through use of immunostimulants (Raa, 2000: and Sahoo and Mukherjee, 2002). Immunostimulants represents an emerging class of chemicals that are designed to amplify immune responses against infectious diseases and tumor cells. The field of essential metalloelement complexes has attracted many authors in the last decade. El-Ashmawy, et al. (2007) and Saad et al. (2013) concluded that, fish supplemented with copper (I) nicotinate complex (either 30 or $60 \mathrm{mg} / \mathrm{kg}$ feed) showed a significant increase in the percentages of most hematological and biochemical parameters. They also aded that both concentrations of copper (1) nicotinate complex had no adverse effect on liver functions, induced immunostimulant effect in tested Big head carp fish and increased the relative level of protection agains injected virulent strain of Yersinia ruckeri. AlMullaHummadi et al. (2005 and 2006) reported that, an organic complex of copper chloride, ascorbic acid and nicotinamide has an immunomodulating effect.
Copper (I) nicotinate complex reduced the adverse effects of 5-fluorouracil on patients with hepatocellular carcinoma and enhanced defense mechanisms against oxidative stress (El-Saadani, 2004) and produced antiulcerogenic activity in rates (El-Saadani et al., 1993). The medical benefitsparticularly the immunostimulant effect of the different coppercomplexes were previously reported by Franklinand Richardson, (1980), El-Ashmawy et al. (2007), Eduardo et al. (2009), and Saad et al. (2013).Therefore, the present study was planned to investigate the effect of dietary supplementation with copper Chelating complex as immunstimulant of catfish Clariasgariepinus.

\section{MATERIALS and METHODS}

\section{Fish:}

Forty African sharptooth catfish with a range of body weight $100-120 \mathrm{~g}$, and length $20-25 \mathrm{~cm}$ were obtained from a private fish farm at Assiut Governorate and transported alive to laboratory at the farm of the Faculty of Agriculture, Assiut University, Assiut, Egypt. Diets and feed additives were formulated to be used for feeding of fish. A basic diet (control) was formulated of grounded yellow corn 
(34.9\%), soya bean meal (28.6\%), fish meal (17.0\%), wheat bran $(9.3 \%)$, vegetable oils $(6.5 \%)$, ground lime stone $(0.70 \%)$, bone meal $(0.30 \%)$, mineral mixture $(1.7 \%)$ and vitamin mixture $(1.0 \%)$, in the form of dry pellets, and the fish were fed with feeding rate $3 \%$ from body weight twice daily.

\section{Copper chelating complex mixed diet:}

Copper albumin chelating complex was obtained from Prof. Nassar-Dept of biochemistry, Faculty of Medicine, Assiut University, as patent cooperation treaty (PCT) in the international Bureau of World Intellectual Property Organization (WIPO), Geneva, Switzerland World Organization (WO) 2008 028497, and mixed with the basal diet as $60 \mathrm{mg} / \mathrm{kg}$ diet.

\section{Aquaria}

Fish were kept for 20 days in the recirculation system in the metallic tank for acclimation to the laboratory conditions, these Fish were to fully prepared aquaria for another 4 days for further acclimation.

\section{Experimental design}

The forty acclimated African catfish, Clariasgariepinus, were used to conduct this study in 2 groups. Fish were randomly divided into 2 groups (20 fish in each group) were used for evaluating the immune blood parameters of fish (blood set), and the challenge experiment. the first group (control group $G$ I)received the basic diet, for 30 days, and the second group received the basal diet mixed with 60 mg copper albumin chelating complex/ $\mathrm{kg}$ basal diet; (G II).

\section{Sample collection \\ Blood smears}

Blood samples were collected from the caudal vein of 5 fish of each group. Giemsa stained blood smears were prepared. Leucocytes were distinguished microscopically on each blood smear and a mean relative percent was calculated.

\section{Serum}

Blood-sera of the examined fish were collected and stored at -80 until used.

\section{Total protein, albumin, globulin in the serum}

Serum protein, albumin, and globulin were estimated spectrophotometrically by using kits, Qualigens Diagnostic, Division of Glaxo Smithkline Pharmaceutical Ltd.

a) Total proteins: Assay of total proteins was carried spectrophotometric at $540 \mathrm{~nm}$, according to Beirut method. Total proteins were expressed in $\mathrm{g} / \mathrm{dl}$

b) Albumin: Serum samples from all experimental groups were estimated spectrophotometrically at $630 \mathrm{~nm}$

c) Globulin: Globulin was calculated by mathematical subtraction of albumin value from total proteins. Globulin was expressed in $\mathrm{g} / \mathrm{dl}$

\section{Bacterial strain used for challenge}

Aeromonase hydrophila, (a localized strain, Elkamel and Thune, 2003).

Bacterial strain was kept in Brain Heart gnfusion broth with $15 \%$ glycerol (EL- Gomhurrhia, Cairo, Egypt) at - 20C. The A. hydrophila strain was passed three times in Cat-fish through intraperitoneal injection before using for experimental challenge. Colony forming unit (CFU) counts in bacterial suspension were determined using spectrophotometry optical density values at wavelength $600 \mathrm{~nm}$ and standard-plate count method with tenfold serialdilution.

\section{Challenge test.}

At the end of 30 days feeding, the fish of each group were injected intra peritoneal $(\mathrm{I} / \mathrm{P})$ with $0.5 \mathrm{ml}$ sterile saline containing $\left(1.5 \times 10^{8} \mathrm{cfu} / \mathrm{ml}\right)$ pathogenic strain of A.hydrophila. The clinical signs, P.M. lesions and mortalities were monitored for 7 days post challenge.

\section{RESULTS}

Table No 1 show the body weight of all fish in the control group as well as well as the treated group. There is no significant differences in the initial body weight (IBW) before treatment at the beginning of the experiment, while the final body weight (FBW), was significantly high in fish of the group (II)fed on copper albumin chelate mixed diet.

Table 1: The Mean Body weight (BW) in Grams of 20 ClariasGariepinusfed with copper chelating complex supplemented diet (GII) compared with the control group (GI) fed with basal diet.

\begin{tabular}{cccccc}
\hline \multirow{2}{*}{$\begin{array}{l}\text { Time } \\
\text { Group }\end{array}$} & Type of feed & \multicolumn{2}{c}{ Before treatment } & \multicolumn{2}{c}{ After 30 days feeding } \\
\cline { 2 - 5 } & Mean BW & SEM & Mean BW & SEM \\
\hline GI & Basal diet & 123.650 & 2.028 & 156.750 & 2.496 \\
\hline GII & $\begin{array}{c}\text { copper chelating complex } \\
\text { supplemented diet }\end{array}$ & 120.600 & 1.792 & 163.950 & 2.037 \\
\hline
\end{tabular}

SEM: Slandered Error Mean 
Differential leucocytes indicated the non-significant higher in the percent of lymphocytes in fish of the GII $(67.600 \pm 1,680 \%)$ and $66.0 \pm 1,520 \%$. in (GI), while the percent of Basophiles $(4.00 \pm 1,049 \%)$ was two times higher than that in the control group $(2.00 \pm 0,577 \%)$. No significant difference in the mean $\%$ of neutrophils, monocytes and eosinophil between the control group (GI) and the treated group (GII) as shown in Table. 2.

Table 2: Differential Leucocytes percent ClariasGariepinus30 days fed, copper chelating complex mixed diet (GII) compared with the control group fed on basal diet (GI).

\begin{tabular}{ccccccccccc}
\hline Group & \multicolumn{2}{c}{ Lymphocytes } & \multicolumn{2}{c}{ Monocytes } & \multicolumn{2}{c}{ Neutrophils } & \multicolumn{2}{c}{ Basophil } & \multicolumn{2}{c}{ Eosinophil } \\
\cline { 2 - 11 } & $\begin{array}{c}\text { Mean } \\
\boldsymbol{\%}\end{array}$ & SEM & $\begin{array}{c}\text { Mean } \\
\boldsymbol{\%}\end{array}$ & SEM & $\begin{array}{c}\text { Mean } \\
\boldsymbol{\%}\end{array}$ & SEM & $\begin{array}{c}\text { Mean } \\
\boldsymbol{\%}\end{array}$ & SEM & $\begin{array}{c}\text { Mean } \\
\boldsymbol{\%}\end{array}$ & SEM \\
\hline GI & 66.000 & 1,520 & 18.00 & 3,512 & 12,00 & 2,082 & 2.000 & 0,577 & 2,000 & 0,577 \\
\hline GII & 67.600 & 1,680 & 13,60 & 1,364 & 9,800 & 0,860 & 4.000 & 1,049 & 2,000 & 0,632 \\
\hline
\end{tabular}

SEM: Slandered Error Mean

Results of the serum biochemistry were presented in Table 3 show a higher total protein in the serum collected from the fish (GII), $(3,567 \pm 0,239 \mathrm{~g} / \mathrm{dl})$ and $\mathrm{GI}(3,117 \pm 0,4080 \mathrm{~g} / \mathrm{dl})$ as well as a high serum globulin \% in fish of GII $(2,100 \mathrm{~g} / \mathrm{dl})$ control group G I $(1,698 \mathrm{~g} / \mathrm{dl})$.

Table 3: Protein profile in serum of Clariasgariepinus groups fed on copper chelating complex mixed diet (GII) for 30 days compared with on fish fed on the basal diet (GI).

\begin{tabular}{ccccc}
\hline \multirow{2}{*}{ Group } & \multicolumn{2}{c}{ GI } & \multicolumn{2}{c}{ GII } \\
\cline { 2 - 5 } & Mean g/dl & SEM & Mean g/dl & SEM \\
\hline Total proteins & 3,117 & 0,408 & 3,567 & 0,239 \\
\hline Albumins & 1,420 & 0,172 & 1,477 & 1,100 \\
\hline Globulins & 1,698 & 0,268 & 2,100 & 0,287 \\
\hline
\end{tabular}

Table 4: Mortality \% of Clariasgariepinus fed with copper chelating complex mixed diet (GII) for 30 days compared with the fish fed with the basal diet (GI) and challenged with A.hydrophila.

\begin{tabular}{lccc}
\hline Fish group & Total number & Number of dead fish & \% of mortality \\
\hline G I & 20 & 7 & 35 \\
\hline G II & 20 & 0 & 0 \\
\hline
\end{tabular}

The results of artificial challenge with A. hydrophila presented in Table 4, showed initial mortality of infected fish beginning at $48 \mathrm{~h}$ after injection and resulting in a final mortality of $35 \%$ at 7 days in fish of the control group. Died fish manifested external signs associated with A. hydrophila infection including redness of the eyes, ecchymosis and exophthalmia in fish of the GI and there were no apparent clinical signs and no mortalities were observed in fish of the group II

\section{DISCUSSION}

The significant higher body weight were observed in fish of the group treated with copper chelating complex mixed diet than that fed on the basal diet in the control group this may attributed to that copper is an essential mineral required for proper bone growth and development as well as enzyme function (McDowell, 1992).

The increase in total protein and globulin of fish administered copper chelating complex mixed diet 
may attributed to the role of copper in protein biosynthesis as it is vitally concerned in the growth process (Minganti et al., 2010). In addition, copper is involved in the formation of disulphide linkage of collagen and elastin proteins (Shalaby et al., 2006). Moreover, the significant increase of serum globulin may indicated the immunostimulant effect of copper chelating complex

The relationship between copper and host immunity was reported by Radostits et al. (2000). Copper deficiency inducealteration in humeral response (Prohaska and Failla, 1993; Radostits et al., 2000; and Gatesoupe 2007). Moreover, the increase of serum globulin may indicated the immunostimulant effect of copper chelating complex.

Copper chelating complex may stimulates the haemopiotic tissues and subsequently led to production of extensive number of effective functional cells like lymphocytes and basophiles as a defense mechanism (El-Ashmawy, 2007). On the other hand the Clariasgariepinus fed on diet supplemented with copper chelating complex show $0 \%$ mortality within one week post challenge in comparison with $35 \%$ mortalities in the non-treated control group suggesting the Immunoptentiator effect of copper chelating complex. Such suggestion was supported by the high level of the serum total protein and globulin and it's increase of the leucocytes that reflected the protective effect against the infection.

It's concluded that, from the presented results, use of copper chelating complex as feed additive for Clariasgariepinus at a dose of $60 \mathrm{mg} / \mathrm{kg}$ of diet for one month has shown to be an activator of nonspecific immune response.

\section{REFERENCES}

Eduardo, G.A.; Gisele, C.F.; Daniela, C.; Fabiana, G. and Jose, C.D. (2009): Dietary supplementation of lysine and/or methionine on performance, nitrogen retention and excretion in pacu Piaractusmesopotamicus reared in cages. Aquaculture. 295: 266-270.

El-Kamel, A.A. and Thune, R.L. (2003): Invasion and replication of photo bacteriumdamselae sub species Piscicida in fish cell lines Jaquatic animal health.15: 167-174.

AL-MullaHummadi, Y.M.; Najim, R.A. and ALBashir, N.M. (2005): Leishmania major and Leishmaniatropica: I. The in vitro effects of an immunomodulator, S2-complex. Exp. Parasitol. 111, 47-54.

Al-MullaHummadi, Y.M.; AL-Bashir, N.M. and Najim, R.A. (2006): Leishmania major and Leishmaniatropica: II. Effect of an immunomodulator, $S$ (2) complex on the enzymes of the parasites. Exp. Parasitol. 112, 85-91.

El -Saadani, M.A. (2004): A combination therapy with copper (1) nicotinate complex reduces the adverse effects of 5-fluorouracil on patient with hepatocellular carcinoma. J. Exp. Ther. Oncol. 4, 19-24.

EL-Saadani, M.A.; Nassar, A.Y. and Abou El-Ela, S.H. (1993): The protective effect of copper complexes against gastric mucosal ulcer in rats. Biochem. Pharmacol. 46, 1011-1018.

El-Ashmawy, I.M.; Saad, T.T.; El-Bahr, S.M. and Salama, O.M. (2007): Assessment of immune response of big head carp fed on copper (1) nicotinate and vaccinated with Yersinia Ruckeribacterin. Veterinary Medicine Journal Giza 2, 507-22.

Franklin, T.A. and Richardson, M.F. (1980): Reactions of metalions and vitamines: III. Synthesis and infrared spectra of metal complexes with pyridoxamine and pyridoxine. Inorganic Chemica Acta46,191-197.

Gatesoupe, F.J. (2007): Live yeasts in the gut: Natural occurrence, dietary introduction, and their effects on fish health and development. Aquaculture, 267: 20-30.

McDonald, P.; Edward, R.A. and Green balgh, J.F. (1995): Animal Nutrition 5th ed. pp. 103-106, English language, Book society

Minganti, V.; Drava, G.; Pellegrini, R. and Siccardi, C. (2010): Trace elements in farmed and wild gilthead Seabream, Sparusaurata. Marine Pollution Bulletin, (60): 2022-2025.

Prohaska, J.R. and Failla, M.L. (1993): Copper and Immunity, 1st ed. New York, Plenum Press.

Raa. J. (1996): The use of immunostimulatory substances in fish and shellfish farming. Rev. Fish. Sci., 4, 229-88.

Radostits, O.M.; Blood, D.C.; Gay C.C. and Hinchcliff, K.W. (2000): Veterinary Medicine: a Textbook of the Diseases of Cattle, Sheep, Pigs, Goats and Horses, Baillière Tindall, London.

Saad T.T.; El-Meadawy, Z.Kh.; ALI M.A. and Fayzal A.I.E. (2013): Some studies on the effect of copper (I) nicotinate complex on the immune response and some Biochemical parameters of sea bass fish vaccinated With Yersinia Ruckeri Bacterin, World's Vet. J. 3(4): 74-81

Sahoo P.K and Mukherjee S.C. (1999): Influence of the immunostimulant chitosan on immune response of healthy and cortisol-treated (labeorohita), J Aqua Trop, 14209-215.

Shalaby, A.M.; khattab, Y.A. and Abdel Rahman, A.M. (2006): Effects of garlic (Allium sativum) and chloramphenicol on growth performance, physiological parameters and survival of Nile tilapia (Oreochromis niloticus) J. Venom. Anim. Toxins incl. Trop. Dis., 12, 2, p. 200 . 


\section{معقد النحاس كمحفز للمناعة في سمك القرموط الافريقى (كلارس جاربينس)}

\section{سعبر بيوسف حسبن ، محمود على عبد النبي ، احد باسبين نصار ، محمد /حد إبراهيم \\ Email: ibrahim.ahmed@mailcity.com}

أجريت هذه الدر اسة لتقييم كفاءة معقد النحاس مع الالبيومين كإضافات للأعلاف في تحسين الاستجابة المناعية ومقاومة الأمر اض في

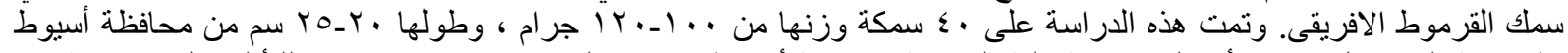

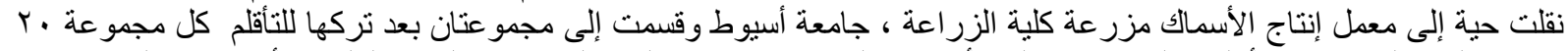

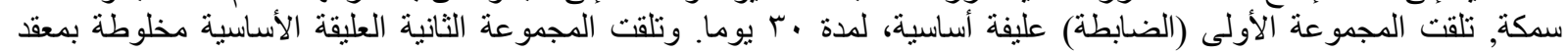

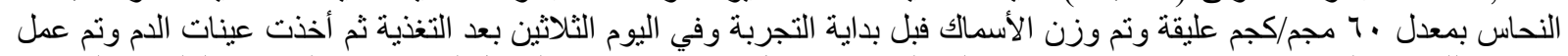

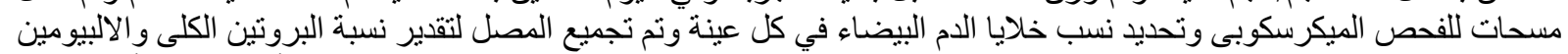

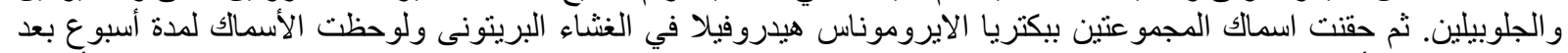

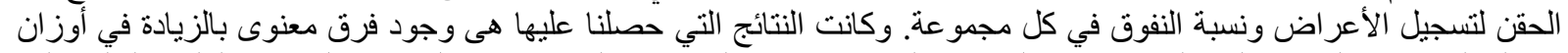

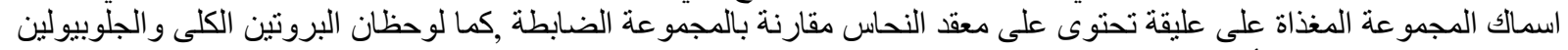

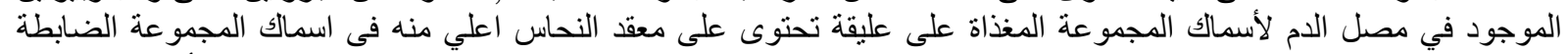

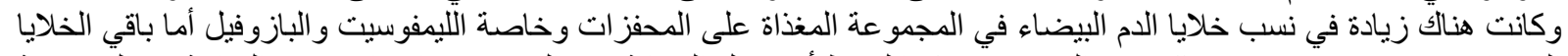

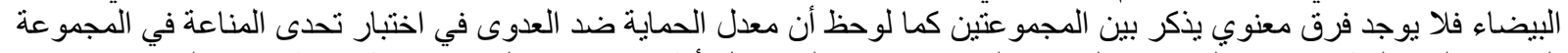

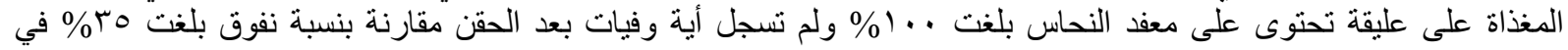

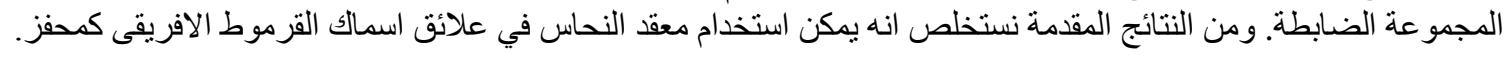

